\title{
Influence of Transformational Leadership Style on Global Competitive Advantage through Innovation and Knowledge
}

\author{
Tuqa Mohamed AlOwais ${ }^{1}$ \\ ${ }^{1} \mathrm{Al}$ Ain University for science and technology, Al-Ain, UAE \\ Correspondence: Tuqa Mohamed AlOwais, Al Ain University for science and technology, Al-Ain, UAE. E-mail: \\ t.alowais87@gmail.com
}

Received: August 6, 2018

Accepted: August 14, 2018

Online Published: December 30, 2018

doi:10.5539/mas.v13n1p183

URL: https://doi.org/10.5539/mas.v13n1p183

\begin{abstract}
Today's business organizations necessitate a new leader who can easily confront a new business approach that mainly based on knowledge and innovation to simplify the organization's path toward global marketing trend. Still; organizations sometimes flop to reach sustainable global competitive advantage due to their imperfect consideration of the relationships between these strategic variables.

In fact, and up to our knowledge, few researches has consider and examine the direct and indirect associations linking these variables. Our study tries to fill this gap by investigating, theoretically and empirically, how the leader's discernment of diverse intermediary strategic variables related to innovation and knowledge (knowledge slake, absorptive capacity, tacitness) and innovation impact the relation between transformational leadership and organizational global competitive advantage. Based on recently published researchers, we developed a theoretical model that demonstrate the actual connection linking these variables.

Most of the data has been collected through secondary resources including journals, books and related research papers. While a questionnaire was used to collect data samples from 50 respondents from Telecommunication Regulatory Authority leaders and employees in UAE, model testing also conscious the findings and deliver some conclusion from business leaders to confirm the relations tested among this research
\end{abstract}

Keywords: transformational leadership style, knowledge management, innovation, global competitive advantage, globalization

\section{Introduction}

Recently, almost all business organizations are facing challenges happens through dynamic business environments portrayed by new business changes, technological advancements, emerging customer's needs, and the need for innovative products. All those challenges lead to emerging globalization approach.

Market competitive advantage facilitates the usage of e-commerce and online shopping approaches through retail customer's shopping experience, this rapid growth of e-marketing, e-commerce, and e-shopping affect the customers shopping decisions that significantly shift the organizations perspective toward attain global market advantage (Nuseir, M. T,2010).

Leadership have many definitions based on different perspectives. (Yukl,2002) define the leadership as the process on which supervisor or manager can effectively coordinates and manages their subordinate's actions with concerns to business goals or objectives. Leaders have different leadership styles that used to describe how the leader impress their power or rules over their subordinates to achieve a specific goal either for a specific task or for the overall business.

Leadership style, through many extended researches evidently proved to be a vital factor that affecting knowledgebased organizations to exploit innovative processes and even initiating global competitive environment (Dereli, 2015)

Manager who looks to drive his organization toward innovation and competitiveness performs distinctive leadership style described as "Transformational Leadership Style". Transformational vs. Transactional leadership styles differ in their actual effect on directing, stimulating, and managing organization's trend toward more creativity and innovation. (Aragón-Correa.el., 2009). The actual effect of this styles appears on both the knowledge 
management and innovation process that composed affect the organization competitive global advantage. Transformational leader managing organizational knowledge through three measurable aspects generating, allocation, and exploiting on both individual and group levels (Bryant 2003).

Knowledge management through organizations, groups, or even among individuals is strongly connected with management perspective that defined as "System based on knowledge". Over this view point the system should be managed through the overall knowledge circle (explicit or tacit), external knowledge (absorptive capability), internal knowledge (knowledge slake). This knowledge stream through the power of transformational leader and innovative business process can impress a significant effect for attaining the global competitive advantage. It is not only the member's knowledge that deliberately significant factor, but the existence of effective leadership style that enable the organization to custom, participate, and share this knowledge flow innovatively.

Innovation, simply can be defined as finding new ways to do things like never done before or by the codification of old ideas to generate a new ideas or ways for understanding. In business this can translated to achieving a novel products and economic growth that works as a base for the total business performance advancements (Pratt, 2018). Therefore, companies exercise themselves to mature new innovative skills, expand sustainable capabilities and upgrade their performances. In this perspective, innovation has been one of the vital essentials of global competitive advantage (Dereli, 2015)

In a globalized world, business organizations have been changed in all dimensions. Due to deviations in the market, the operative of the companies and markets has also changed. As of expanded business burdens, needs and production arrangements, new businesses appeared and also new production process and attitude have grown. Therefore, existing business setups and settings are not adequate or applicable, companies need innovative procedures and approaches in such global competition. Though creativity and innovation that based on organizational knowledge management become the main principal of companies to receive attainment at unlimited and flexible market circumstances (Bozkurt, 2000).

By addressing this issues, in the existing study we contend that the relationship or connection between the organization's transformational leadership style and attaining global competitive advantage is contingent with boosting knowledge and innovation among all business aspects, especially by motivation and inspiration nature of transformational leadership in initiating effective engendering knowledge-based and innovative behaviors among all business organization's levels.

To test the study model, the following hypothesis has been studied through next section and illustrated in figure 1

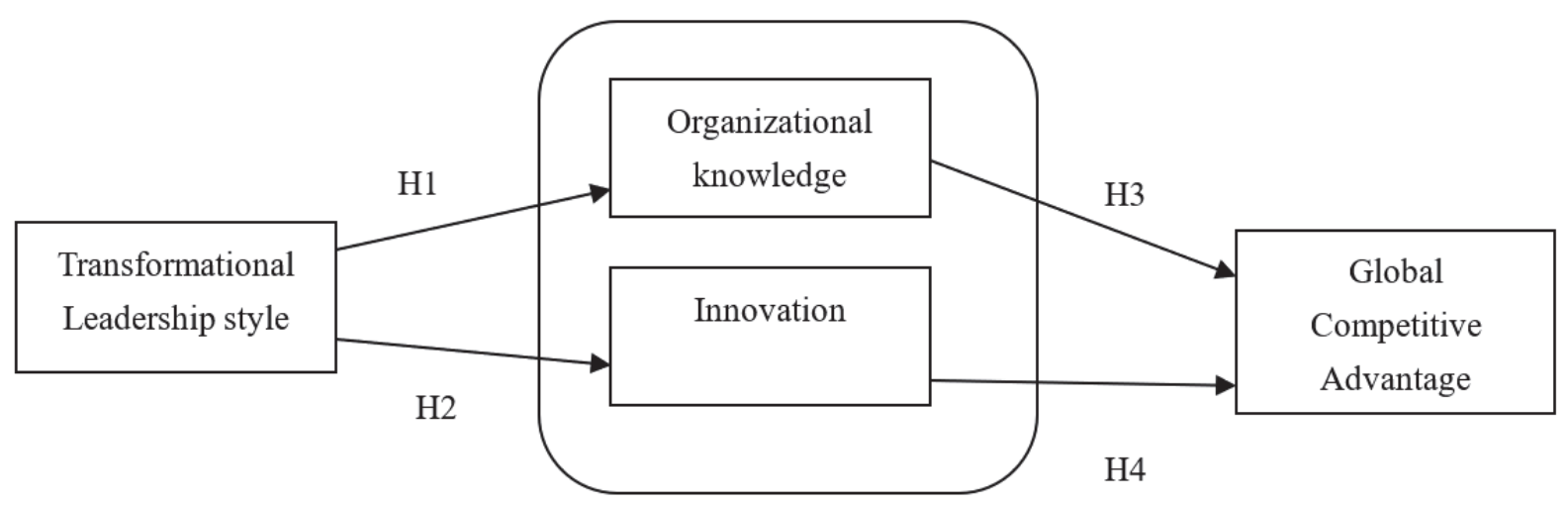

Figure 1. Proposed system's framework

\section{Theoretical Background and Hypothesis Development}

The approach of 7-S model from Mc Kinsey, Singh (2013) (Note 1) have confidence in that transformational leadership style had a starring role in preserving and emerging a company's sustainable global competitive advantage through effective association of center communications. The research findings of (Menguc et al. 2007) stated that transformational leadership definitely and positively effect on marketing distinction and variation and enforce a low cost strategy, combined together leads to attain global competitive advantage. Based on theoretical thinking and empirical study results, hypothesis was formulated here below as follows:

\section{Transformational Leadership and Organizational knowledge}

Transformational leaders can be defined as the leaders who work and motivate their subordinated to identify 
business vision, needed change, and thus share all business responsibilities. Based on this, transformational leadership can describe the leader style that effectively transform or change followers to escalate beyond their selfinterest by changing their ethics, interests, and scruples. Accordingly encourage them to execute superior than anticipated and work as a role model for scarifying self-achievements for group or collective-achievements (Bass, 1990).

Transformational leadership can see as an advantage over transactional leadership whose works as a higher-level constructor conceding the dependent or reliable on rewarding their followers and specifically doing "managementby-exception" (i.e. observing performance measures and taking curative and helpful movements when problem ascend). (Avolio, Bass, \& Jung, 1999).

As transformational leadership considered on the total contrast with transactional leadership, we prefer to incorporate transactional leadership in our analysis. Besides, this contrasts provide an evident on that transformation leadership is not only work as a behavior but more extend to initiative transform that leads to attain more innovative way of thinking and thus affect the organization's innovation culture and trend (Pieterse, 2010).

Transformational leader has his/her own characteristics that facilitate his impact to different business and personnel approaches. Transformational leader has attractiveness, personality, intelligent stimulation, encouragement. This style effectively builds a new communication channels among followers based on respect, trust, knowledge share that leads to effective knowledge management approach (Bass, B. M., Avolio, 2003).

Knowledge generally uncertain due to many changes of its absorbing, discussing and manipulating. So that knowledge slack becomes important by enhancing the possibilities of fresh information that efficiently resembles current ones, and thus the possibility of adopting knowledge management process successfully (Cohen, W. M., \& Leventhal, 2000). Business information absorbed new and innovative ones easily if the existing or previous information having some kind of similarities. This absorptive capacity strongly related with the organizational existing knowledge and on the same time, absorptive capacity strongly affected innovative capabilities and innovative attitude (Liao, S. H., Fei, 2007).

Transformational leader also has a positive impact on knowledge absorptive capacity through his influence of the followers or subordinates' individual absorption. Individual absorption required an effective division and assignment of business responsibilities and authorities among workers. This becomes easy if transformational leader innovates new processes to expand responsibilities effectively, his power evidently matches a suitable organization structure to finally get the maximum absorption capacity (this may happen through merger and acquisition, business cultural change), using explicit and tacit knowledge.

Tacit knowledge considered as more-strategic as explicit; facilitate the easy route toward attaining global competitive advantage and strongly related to different strategic significant variables like innovation capability (Liao,2007).For transformational leadership, innovation capabilities considered as a focal thinking point for such style, this concept of leadership can be connected to innovation through his way/s to transform old ideas into moreinnovative ones and by inspiring his followers to think differently, seeking for new problem solving opportunities and creating investigative thoughts processes This style works as a role model in expressing a shared vision of innovation.(Schepers, 2007).

Therefore, this study suggests that there is a positive relationship between transformational leadership and organizational knowledge aspects (knowledge slake, absorptive capacity, tacitness). these aspects are abstracted and put into a formalized theory including a complete and sophisticated knowledge management system.

From what we have presented above, we can formalize Hypothesis 1 that will be tested for soundness later on with more evidences from on-field studies.

Hypothesis 1: Transformational leadership has a positive effect on organizational knowledge.

\section{Transformational Leadership and Innovation}

Innovative behavior can be compromise into a multi-steps process starting from problem understanding and recognition, flowed by suitable idea generation and upcoming solution, through reaching finally to the actual idea realization and achievement. (Yukl, 2002). Thus many researches argues how innovative behavior influences by abilities, skills, and specific knowledge (Amabile, 1988) while others insists it is strongly related with motivational factor that turn it into extensive concentration throughout many leadership researches (Glynn, 1996).

It is essential to differentiate two strongly-related definitions "invention and innovation". Whereas invention can be stated as establishment of an idea around a new product or business process, innovation is to bring out this new idea into reality. As of this diverse necessities in creating new ideas and employing them, a time interval befalls 
between invention and innovation. Changed types of understanding, abilities and properties are desirable in order to transfer an invention into an innovation (Fagerberg,2005).

A number of studies stated that transformational leader initiates an innovative business climate. (Jung et al. 2003), who's research testing conducted on 32 Taiwanese companies, found a positive impact of transformational leader on the companies' innovative approaches through stimulating motivation and intelligent innovation stimulation. Such leadership style, and through articulating the organizational vision will spread a power of confident that make their followers acts the same, and will strive to attain innovative market (Jung et al. 2003).

Transformational leader, not only extent an internal innovation, his role extends to external innovation aspects like championing and boundary crossing and bridging. This considered a crucial factor to understand the global market requirements and global customer's needs. Therefore

Hypothesis 2: Transformational leadership has a positive effect on organizational innovation.

Knowledge Slack, Absorptive Capacity, and Global Competitive Advantage

Organizational adaptability can be strongly related to how organization quickly adapt and accordingly adjust to business environment changes in existing compound and challenge business environment. Adaptability requires efficient absorptive capacity to transfer best performs, follows and knowledge (Daghfous, 2004).

On the same path, absorptive capacity fundamentally relies on the level of preceding correlated knowledge; not only basic accountabilities, abilities, skills but also pioneering technological and social advances. On the other hand, knowledge slake strictly linked to new and innovative knowledge, so that it simplifies absorptive capacity, this capacity need more knowledge slake to be maintained and continue(Zahra, 2002).

Knowledge slake is critical to the organization's capacities and talents to engage and advance knowledge and intellectual wealth. However, the ordinary presence of knowledge slakes or investment in its progress is not sufficient for attaining the market competitive advantage.

Absorptive capacity which when related to competitive advantage can be defines as the ability of business organizations to understand and completely recognize the value of new, innovative external business information, absorb it, and practically implement it into competitive business results which is not only affect innovation (Zahra, 2002) but extends to cover many business significant areas like global marketing (Xiong and Bharadwaj, 2011) and international business (Lyles \& Salk, 1996).

In general, Knowledge management system(KMS) is the second state-of-the-art innovation relevant to business practitioners. with KMS distinct as "a total networked system that share information via a knowledge slake and influence knowledge all over the enterprise" in addition to "offer Internet based entrance to clients and provider worldwide". (Alavi,2001) discussed in his study how the great developments and advancements in knowledge management system initiate and maintain the competitive advantage.

All of the research mentioned above leads to formalizing hypothesis 3 mentioned here:

Hypothesis 3: Organizational knowledge will be a mediator between transformational leadership and organizational global competitive advantage

\section{Innovation and Global Competitive Advantage}

Studies and researches that interested in aspects related to economic growth and development, investigate the strong relation between innovation and competitive advantage. While the need for differentiation required innovative thinking, each new innovation forces a new competition advantages, conditions, consequences and implications. Shortly Innovation and competition influence each other. On other words Competition is an ambition for innovation creativities. On the other side innovation supports competition whereas making it more concentrated (Noe, 2003).

Recently, high competition either regionally or globally exists. Organizations have to adopt new innovations or be innovative by itself to survive and continue in such high-competitive market. Dynamic changes of competition forces new innovative ways rather than traditional methods just like recruiting a cheap labor or ordinary economic growth approach. Rather, innovation variable is the best strategic variable for competitive advantage especially when the company look for globalization. (Özdemir,2012) in his study found that innovation has significant effect on organization efficiency, performance, and growth. Competitive advantage gained through innovation also affect employee's satisfaction, employment procedures and prosperity gains.

On the other direction, Competition shape a pressure on organizations to look for differentiation through innovation. Innovative companies are appreciative to accept the innovation implementation extra costs to be born in instance 
of undesirability of the current corporal and human infrastructure. Competitive burdens shaped by the existence of competitors has to be further added at this topic.

Innovation is the driving factor stands behind many success companies' stories, it is the keystone for global competition and global advantage. Innovation considered an essential impact that affect most organizational factors including profitability, service quality standards, and most importantly aid in attaining customer's loyalty with organizational product's (Nuseir,2015). (Açıkdilli,2013) in his study stated some concerns and procedures related to global market conditions determined by innovative approach, some of them are:

Innovation is a life style, rather than a number of continuous business steps. Organizations with all sizes (small, medium, and large) have to look for new, creative, and innovative opportunities to continue or DIE. Innovation can either be on idea, process, product, or even service. For the best implementation of innovative strategies, it is better to put-in-hand new changes including process, technology, and management and observe them closely. Despite the fact that there is an excessive costs related with innovation implementation, innovation can be implemented by just new effective ideas.

According to Porter five-forces(Porter,2008) there are essential principles for organizations to attain the global competitive advantage, the first principle is the effective handle of the organization's value system, and beside to that all the resources must be continually advanced and investigated, and finally innovation and change requisite to be sustainable. Hypothesis 4 formalized the assumptions deducted from the literature research mentioned in this section.

Hypothesis 4: Organizational Innovation will be a mediator between transformational leadership and organizational global competitive advantage.

The main intention behind this study is to conclude whether leaders in managerial positions in the "UAE Telecommunication Regularity Authority(TRA)" (Note 2) who are in charge of vital decision making and managerial responsibilities have characteristics of transformational leadership styles. Perceptions of organizational knowledge management, An implementation of innovative approaches via business processes, product, and services. How this perception positively mediate effects between transformational leadership and organizational global competitive advantage. Therefore, this study passes in concluding the tested relations

\section{Methodology}

\subsection{Sample and Procedure}

Our research sample targeted "UAE Telecommunication Regularity Authority(TRA)" (Note 3) leaders and employees regarding the actual relationship among transformational leadership, applied knowledge management system, innovation, and the way to attain the Authority competitive advantage.

TRA as our research analysis field or unit is the authorized UAE partner in carrying all the responsibilities related to the management and supervision of every telecommunication and information technology aspects (ICT).Despite its short life span compared to other regional authorities, But we choose it since its exceeding expectations in achieving creativity and innovation that evidently touched through its innovative services and global competence in promoting initiative ways to offer the best services to the UAE society citizens.

TRA through its ambitious toward attaining service global competitiveness, participate and win many local, regional, and global awards related to ICT sector. This innovative involvement in such awards will throw in producing an environment encouraging the development advancements and innovation through helpful competition between government units at the local, regional and global stages. It also present suggested and recommended tools to contest international standards and propose government authorities an open proposal to become skilled of thriving ICT performs.

For our study, we have used purposive sampling (Tongco,2007) mainly targeting TRA leaders and employees for whom their innovation and competitiveness ambitious are very important and noticed. To avoid the "Common method Variance (CMV)" problems since in this research we measure one dependent variable and other intermediate one. (Eichhorn, 2014). So that we use two separate surveys to gather the dependent and independent variables related data. One for the TRA's managers and the other for the employees.

Senior managers were request to respond to the degree of the technological innovation implementation and embracing, in addition to questions related to the company ambitious toward achieving and maintaining globalization trends while employees were asked to respond to the questions relating to transformational leadership behaviors attributable to their direct or indirect senior managers. TRA total size at the end of 2017 was 1300 employees (as mentioned in the official website open data tab). 70 percent of employees in our sample were in the 
customer service departments while the rest 30 percent worked in other managerial work positions

Applicable and usable matching data were gather from 50 total respondent divided into 20 senior managers and 30 employees.

\subsection{Measures}

Transformational leadership attributes were assessed and measures reflectively by five pointers: idealized influence attributes, idealized influence behaviors, encouragement motivation, intellectual stimulation, and individualized consideration, adapted from Multifactor Leadership Questionnaire (MLQ) from (Bass and Avolio ,2000).

Knowledge and innovation was assessed formatively also from sign of product innovation, service innovation, organizational innovation, adapted from Innovation Diagnosis Questionnaire (IDQ) from Mckinsy and Company.

Finally, the competitive advantage of TRA was considered based on one or more indicators: exceptionality of products and services, product and service variant, product cost/ value, firm reputation and customer satisfaction, adapted from (Reniati2013). The questionnaire items first passed the validity test to ensure questions reliability.

\subsection{Results and Literature Model}

In this research, we mainly depend on investigating, comparing and critically evaluate the different literatures related to our research topics. After that we construct our Research Theoretical Framework that illustrates the research testing hypothesis.

Research critically finds that Transformational leadership affects the dynamic potentials of organizational knowledge and innovation, supporting Hypotheses 1 and 2, respectively. However, Hypothesis 2 and 3 also shows that the mediation relation that correlate organizational knowledge and innovation successes to attain the global competitive advantage.

The research concludes the indirect relation between transformational leadership style in attaining the organizational global competitive advantage through organizational Innovation and knowledge (measured by knowledge slake, tacitness, and absorptive capacity factors).

In the process of testing the theoretical framework for this research, we shape a number of nested and correlated other hypothesis models, each integrate different hypothesis about considerations and correlations. Evaluation and assessment to rational alternative models is suggested to prove that a "hypothesized model" considered the top demonstration of the exploratory research's data.

\subsection{Research Findings}

Based on the aforementioned results, we were able to formalize the following findings:

1. Building the conceptual model to incorporated the effect of transformational leadership indirectly through knowledge and innovation significantly to organizations global competitive advantage.

2. Organizational knowledge and innovation consider as a two perfect mediation variables of transformational leadership effects on organizations global competitive advantage.

\subsection{Research Limitations}

This research might be limited by the attitude of the questionnaire respondents who were very sensitive in regards with their perception towards their management leadership styles, and so that potentially decrease the independence and objectivity of respondents in responding to questionnaires and freely express their opinions.

\section{Conclusion}

Effective transformational leadership through the employment of influence of ideal features, the inspiration of ideal behavior, stimulating motivation, intellectual stimulation, and personnel considerations directly cannot escalate and enhance the global competitive advantage. Effective transformational leadership can advance and progress organizational knowledge management and innovation approach. Additionally, high innovation can improve the competitive advantage. Innovation and organizational knowledge mediated flawlessly the effect of transformational leadership on competitive advantage.

In this research, the research model framework assigns the required hypothesis to evidently test the research variable correlations. Therefore, the results of empirical studies form the basis of this research hypotheses.

\section{References}

Açıkdilli, G., \& Ayhan, D. Y. (2013). Dynamic capabilities and entrepreneurial orientation in the new product 
development. International Journal of Business and Social Science, 4(11), 144-150.

Alavi, M., \& Leidner, D. E. (2001). Knowledge management and knowledge management systems: Conceptual foundations and research issues. MIS quarterly, 107-136.

Amabile, T. M. (1988). A model of creativity and innovation in organizations. Research in Organizational Behavior, 10(1), 123-167.

American Psychological Association. (1972). Ethical standards of psychologists. Washington, DC: American Psychological Association.

Aragón-Correa, J. A., García-Morales, V. J., \& Cordón-Pozo, E. (2007). Leadership and organizational learning's role on innovation and performance: Lessons from Spain. Industrial Marketing Management, 36(3), 349-359. https://doi.org/10.1016/j.indmarman.2005.09.006

Avolio, B. J., Bass, B. M., \& Jung, D. I. (1999). Re-examining the components of transformational and transactional leadership using the Multifactor Leadership. Journal of Occupational and Organizational Psychology, 72(4), 441-462. https://doi.org/10.1348/096317999166789.

Bass, B. M., \&Avolio, B. J. (1990). Developing transformational leadership: 1992 and beyond. Journal of European Industrial Training, 14(5).

Bass, B. M., Avolio, B. J., Jung, D. I., \& Berson, Y. (2003). Predicting unit performance by assessing transformational and transactional leadership. Journal of Applied Psychology, 88(2), 207. https://doi.org/10.1037/0021-9010.88.2.207

Bozkurt, V. (2000). Gözetimve internet: Özelyaşamınsonumu. BirikimDergisi, 136, 75-81.

Bryant, S. E. (2003). The role of transformational and transactional leadership in creating, sharing and exploiting organizational knowledge. Journal of Leadership \& Organizational Studies, 9(4), 32-44. https://doi.org/10.1177/107179190300900403

Cohen, W. M., \& Levinthal, D. A. (2000). Absorptive capacity: A new perspective on learning and innovation. In Strategic Learning in a Knowledge economy (pp. 39-67). https://doi.org/10.2307/2393553

Daghfous, A. (2004). Absorptive capacity and the implementation of knowledge-intensive best practices. SAM Advanced Management Journal, 69(2), 21.

Dereli, D. D. (2015). Innovation management in global competition and competitive advantage. Procedia-Social and Behavioral Sciences, 195, 1365-1370. https://doi.org/10.1016/j.sbspro.2015.06.323

Eichhorn, B. R. (2014). Common method variance techniques. Cleveland State University, Department of Operations \& Supply Chain Management. Cleveland, OH: SAS Institute Inc.

Fagerberg, J., Mowery, D. C., \& Nelson, R. R. (Eds.). (2005). The Oxford handbook of innovation. Oxford university press. https://doi.org/10.1093/oxfordhb/9780199694945.001.0001

Glynn, M. A. (1996). Innovative genius: A framework for relating individual and organizational intelligences to innovation. Academy of Management Review, 21(4), 1081-1111. https://doi.org/10.2307/259165

Jung, D. I., Chow, C., \& Wu, A. (2003). The role of transformational leadership in enhancing organizational innovation: Hypotheses and some preliminary findings. The Leadership Quarterly, 14(4-5), 525-544. https://doi.org/10.1016/S1048-9843(03)00050-X

Leidner, D. E. (2010). Globalization, culture, and information: Towards global knowledge transparency. The Journal of Strategic Information Systems, 19(2), 69-77.

Liao, S. H., Fei, W. C., \& Chen, C. C. (2007). Knowledge sharing, absorptive capacity, and innovation capability: An empirical study of Taiwan's knowledge-intensive industries. Journal of Information Science, 33(3), 340359. https://doi.org/10.1177/0165551506070739

Lyles, M. A., \& Salk, J. E. (1996). Knowledge acquisition from foreign parents in international joint ventures: An empirical examination in the Hungarian context. Journal of International Business Studies, 27(5), 877-903.

Menguc, B., Auh, S., \& Shih, E. (2007). Transformational leadership and market orientation: Implications for the implementation of competitive strategies and business unit performance. Journal of Business Research, 60(4), 314-321. https://doi.org/10.1016/j.jbusres.2006.12.008

Noe, R. A., Hollenbeck, J. R., Gerhart, B., \& Wright, P. M. (2003). Gaining a competitive advantage. Irwin: McGraw-Hill. 
Nuseir, M. T., \& Madanat, H. (2015). 4Ps: A strategy to secure customers' loyalty via customer satisfaction. International Journal of Marketing Studies, 7(4), 78.

Nuseir, M. T., Arora, N., Al-Masri, M. M., \& Gharaibeh, M. (2010). Evidence of Online Shopping: A Consumer Perspective. International Review of Business Research Papers, 6(5), 90-106.

Özdemir, Ö. G. (2012). Economic Development and Entrepreneurship: The Role of Innovative Entrepreneurship on New Value Creation. Social Sciences, 7(1), 1-18.

Pieterse, A. N., Van Knippenberg, D., Schippers, M., \& Stam, D. (2010). Transformational and transactional leadership and innovative behavior: The moderating role of psychological empowerment. Journal of Organizational Behavior, 31(4), 609-623. https://doi.org/10.1002/job.650

Porter, M. E. (2008). The five competitive forces that shape strategy. Harvard Business Review, 86(1), 25-40.

Pratt, A. C. (2008). Innovation and creativity. The sage companion to the city, 226-297.

Schepers, P., \& Van den Berg, P. T. (2007). Social factors of work-environment creativity. Journal of Business and Psychology, 21(3), 407-428.

Tongco, M. D. C. (2007). Purposive sampling as a tool for informant selection. Ethnobotany Research and Applications, 5, 147-158.

Xiong, G., \& Bharadwaj, S. (2011). Social capital of young technology firms and their IPO values: The complementary role of relevant absorptive capacity. Journal of Marketing, 75(6), 87-104.

Yukl, G., \& Chavez, C. (2002). Influence tactics and leader effectiveness. Leadership, 139-165. https://doi.org/10.14396/jhrmr.2013.20.4.227

Zahra, S. A., \& George, G. (2002). Absorptive capacity: A review, reconceptualization, and extension. Academy of Management Review, 27(2), 185-203.

\section{Notes}

Note 1. https://www.mindtools.com/pages/article/newSTR_91.htm

Note 2. https://www.tra.gov.ae/en/about-tra.aspx

Note 3. https://www.tra.gov.ae/en/about-tra.aspx

\section{Appendix A}

\section{Transformational Leadership}

1. The organization's management strive to attain new business opportunities using all innovative resources and available beneficial knowledge.

2. The organizational management has a comprehensive and clear outlook of their organization's long term objectives, aim, and vision.

3. Leaders effectively can motivate, inspire, and guide their followers to reach the effective implementation of their organizational objectives.

\section{Knowledge Slack}

1. The organizations depend on plentiful resources and previous existed knowledge slake to boost the development and spread of new knowledge needed to accomplish a certain task/s.

2. Knowledge Slack considered an old-new hot topic among organizational researches that occupies a high percentage of investments

\section{Absorptive Capacity}

1. Leading organizations has a clear, robust and complete division of rules and responsibilities for gaining an advantage knowledge.

2. Organization should obtain the essential needed skills to realize new attained knowledge

\section{Tacitness}

1. Used to assign the necessary tasks for a pre-defined job position. 
2. Procedures of how to act/react according to certain situation cannot be easily expressed in written document.

3. Documents and organizational records are an essential parts to explain the critical parts of the organizations useful, dynamic and helpful processes.

\section{Appendix B}

\section{Questionnaire}

\begin{tabular}{|c|c|c|c|c|c|}
\hline Questions & 1 & 2 & 3 & 4 & 5 \\
\hline $\begin{array}{l}\text { Our innovation performance is } \\
\text { better than that of other } \\
\text { government entities in our } \\
\text { country }\end{array}$ & $\begin{array}{c}\text { Strongly } \\
\text { Agree }\end{array}$ & Agree & Neutral & Disagree & $\begin{array}{l}\text { Strongly } \\
\text { Disagree }\end{array}$ \\
\hline $\begin{array}{l}\text { Over the past } 3 \text { years, our } \\
\text { innovations have had more } \\
\text { impact on citizens, businesses, } \\
\text { employees and government than } \\
\text { those of other government } \\
\text { entities in our country }\end{array}$ & $\begin{array}{c}\text { Strongly } \\
\text { Agree }\end{array}$ & Agree & Neutral & Disagree & $\begin{array}{l}\text { Strongly } \\
\text { Disagree }\end{array}$ \\
\hline $\begin{array}{l}\text { We are more successful at } \\
\text { leveraging insights and data to } \\
\text { innovate }\end{array}$ & $\begin{array}{c}\text { Strongly } \\
\text { Agree }\end{array}$ & Agree & Neutral & Disagree & $\begin{array}{l}\text { Strongly } \\
\text { Disagree }\end{array}$ \\
\hline $\begin{array}{l}\text { We are more successful at } \\
\text { developing innovative processes } \\
\text { which significantly improve the } \\
\text { way we serve our stakeholders }\end{array}$ & $\begin{array}{c}\text { Strongly } \\
\text { Agree }\end{array}$ & Agree & Neutral & Disagree & $\begin{array}{l}\text { Strongly } \\
\text { Disagree }\end{array}$ \\
\hline $\begin{array}{l}\text { What portion of the services } \\
\text { your organization delivers to its } \\
\text { stakeholders (citizens, } \\
\text { businesses, employees or other } \\
\text { government entities) over the } \\
\text { past } 3 \text { years can be attributed to } \\
\text { innovations recently developed } \\
\text { in-house and launched? }\end{array}$ & $100 \%$ & $60-79 \%$ & $40-59 \%$ & $20-39 \%$ & $1-19 \%$ \\
\hline $\begin{array}{l}\text { We have a more efficient } \\
\text { process for developing and } \\
\text { scaling innovation }\end{array}$ & $\begin{array}{c}\text { Strongly } \\
\text { Agree }\end{array}$ & Agree & Neutral & Disagree & $\begin{array}{l}\text { Strongly } \\
\text { Disagree }\end{array}$ \\
\hline $\begin{array}{l}\text { What type of innovation will } \\
\text { have the biggest impact on how } \\
\text { you deliver services to your } \\
\text { stakeholders (including citizens, } \\
\text { businesses, employees and } \\
\text { government entities) over the } \\
\text { next } 5 \text { years? }\end{array}$ & $\begin{array}{l}\text { Increased } \\
\text { digitalization } \\
\text { of services } \\
\text { provided }\end{array}$ & $\begin{array}{l}\text { New internal } \\
\text { processes to } \\
\text { improve } \\
\text { efficiency } \\
\text { and service } \\
\text { levels }\end{array}$ & $\begin{array}{l}\text { Access to new } \\
\text { sources of insights } \\
\text { (e.g., increased use } \\
\text { of data, crowd } \\
\text { sourcing, citizen } \\
\text { participation) }\end{array}$ & $\begin{array}{l}\text { New delivery channels } \\
\text { beyond own entity } \\
\text { (e.g., partnerships with } \\
\text { the private sector, } \\
\text { partnerships with civil } \\
\text { society, partnerships } \\
\text { with other government } \\
\text { entities) }\end{array}$ & $\begin{array}{l}\text { Meeting new } \\
\text { needs of citizens, } \\
\text { businesses, } \\
\text { employees and } \\
\text { other } \\
\text { government } \\
\text { entities }\end{array}$ \\
\hline
\end{tabular}

\section{Copyrights}

Copyright for this article is retained by the author(s), with first publication rights granted to the journal.

This is an open-access article distributed under the terms and conditions of the Creative Commons Attribution license (http://creativecommons.org/licenses/by/4.0/). 